\title{
The effects of thyme essential oil and vitamin combinations on performance, carcass quality and oxidation parameters in broilers exposed to heat stress
}

\author{
Savaş SARIÖZKAN ${ }^{1, a}$, Berrin KOCAOĞLU GÜÇLÜ ${ }^{2, b}$, Yusuf KONCA ${ }^{3, c}$, Eray AKTUĞ $\breve{G}^{2, d, \bowtie, ~}$ \\ Mahmut KALİBER ${ }^{3, \mathrm{e}}$, Selma BÜYÜKKILIÇ BEYZi ${ }^{3, f}$, Meryem ŞENTÜRK ${ }^{4, \mathrm{~g}}$
}

\begin{abstract}
${ }^{1}$ Erciyes University, Faculty of Veterinary Medicine, Department of Animal Health Economics and Management, Kayseri; ${ }^{2}$ Erciyes University, Faculty of Veterinary Medicine, Department of Animal Nutrition and Nutritional Diseases, Kayseri; ${ }^{3}$ Erciyes University, Faculty of Agriculture, Department of Animal Science, Kayseri; ${ }^{4}$ Erciyes University, Faculty of Veterinary Medicine, Department of Biochemistry, Kayseri, Turkey.

aORCID: 0000-0003-2491-5152; ' 'ORCID:0000-0003-0341-4594; ' ORCID: 0000-0002-6231-1512; ' ORCID: 0000-0003-2799-9478;

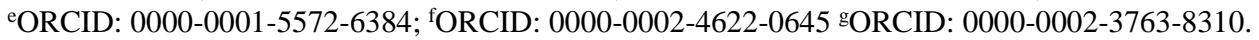

Corresponding author: erayaktug@ hotmail.com Received date: 30.09 .2019 - Accepted date: 17.03 .2020

\begin{abstract}
This study aims to determine the effect of thyme essential oil (TEO) and a combination of TEO with different vitamins (A, C and E) on performance, carcass quality, oxidation parameters in broilers exposed to heat stress (HS). A total of 300, 21 days old, male Ross-308 chicks were distributed in six experimental groups with five replicates. The broilers in $\mathrm{HS}$ groups were exposed to $34^{\circ} \mathrm{C}$ for nine hours per day between 21 and 41 days of the experiment. The experimental groups were as follows: 1: Thermoneutral control (TNC, $\left.22^{\circ} \mathrm{C}\right), 2$ : Heat stress control $\left(\mathrm{HSC}, 34^{\circ} \mathrm{C}\right), 3$ : TEO $\left(300 \mathrm{mg} / \mathrm{kg} \mathrm{TEO}, 34^{\circ} \mathrm{C}\right), 4:$ TEO + Vit C $(300 \mathrm{mg} / \mathrm{kg} \mathrm{TEO}+250 \mathrm{mg} / \mathrm{kg} \mathrm{Vit}$ $\left.\mathrm{C}, 34^{\circ} \mathrm{C}\right), 5: \mathrm{TEO}+\mathrm{Vit} \mathrm{E}\left(300 \mathrm{mg} / \mathrm{kg} \mathrm{TEO}+250 \mathrm{mg} / \mathrm{kg} \mathrm{Vit} \mathrm{E}, 34^{\circ} \mathrm{C}\right)$ and 6: TEO + Vit A $(300 \mathrm{mg} / \mathrm{kg} \mathrm{TEO}+15000 \mathrm{IU} / \mathrm{kg} \mathrm{Vit} \mathrm{A}$, $34^{\circ} \mathrm{C}$ ). As a result, it was determined that HS significantly reduced live weight (LW), live weight gain (LWG), and feed intake (FI) values compared to the TNC group $(\mathrm{P}<0.05)$. Supplementation of TEO or TEO and vitamin $(\mathrm{A}, \mathrm{C}, \mathrm{E})$ combinations to the feed of broilers exposed to HS had no significant effect on performance, carcass quality, carcass part yields, and serum parameters. Economically, the highest profitability was obtained in the TNC group $(\mathrm{P}<0.001)$, In conclusion, HS negatively affected the performance of broilers, and the supplementation of TEO + Vit E to the diet had slightly reduced the adverse effects of HS.
\end{abstract}

Keywords: Broiler, heat stress, performance, thyme essential oil, vitamin

Isı stresine maruz bırakılan broylerlerde kekik esansiyel yağı ve vitamin kombinasyonunun büyüme performansı, karkas kalitesi ve oksidasyon parametrelerine etkisi

Özet: Bu çalışma, 1sı stresine (HS) maruz bırakılan broylerlerde yeme ilave edilen kekik esansiyel yağı (TEO) ve TEO'nun farklı vitaminlerle (A, C ve E) kombinasyonunun performans, karkas kalitesi ve oksidasyon parametrelerine etkisini belirlemek amacıyla yapıldı. Toplam 300 adet, 21 günlük yaşta, Ross-308 ırkı erkek piliç 6 deneme grubuna 5 tekerrürlü olarak dağıtıldı. HS oluşturulan gruplar 21.- 41. günler arasında, günde 9 saat $34^{\circ} \mathrm{C}$ sıcaklığa maruz birakıldı. Deneme grupları: 1: Termonötral kontrol $\left(\mathrm{TNC}, 22^{\circ} \mathrm{C}\right)$, 2: Is1 stresi kontrol (HSC, $\left.34^{\circ} \mathrm{C}\right), 3$ : TEO $\left(300 \mathrm{mg} / \mathrm{kg} \mathrm{TEO}, 34^{\circ} \mathrm{C}\right), 4: \mathrm{TEO}+\mathrm{Vit} \mathrm{C}(300 \mathrm{mg} / \mathrm{kg} \mathrm{TEO}+250 \mathrm{mg} / \mathrm{kg} \mathrm{Vit} \mathrm{C}$, $\left.34^{\circ} \mathrm{C}\right), 5: \mathrm{TEO}+$ Vit E $\left(300 \mathrm{mg} / \mathrm{kg}\right.$ TEO $\left.+250 \mathrm{mg} / \mathrm{kg} \mathrm{Vit} \mathrm{E,} 34^{\circ} \mathrm{C}\right)$ ve $6: \mathrm{TEO}+\mathrm{Vit} \mathrm{A}\left(300 \mathrm{mg} / \mathrm{kg} \mathrm{TEO}+15000 \mathrm{IU} / \mathrm{kg}\right.$ Vit A, $\left.34^{\circ} \mathrm{C}\right)$ şeklinde oluşturuldu. Çalışma sonunda HS'nin canlı ağılık (LW), canlı ağılık artışı (LWG) ve yem tüketimi (FI) değerlerini TNC grubuna göre önemli derecede azalttığı $(\mathrm{P}<0,05)$ belirlendi. Isı stresine maruz birakılan broylerlerin yemlerine kekik yağı veya kekik yağının vitaminlerle (A, C, E) birlikte ilave edilmesinin performans, karkas kalitesi ve karkas parça oranı ile serum parametrelerine önemli bir etkisi olmadı. Ekonomik olarak en yüksek karlılık TNC grubunda elde edildi $(\mathrm{P}<0,001)$. Sonuç olarak, HS'nin broilerlerin performans değerlerini olumsuz etkilediği, rasyona TEO+Vit E'nin birlikte ilave edilmesinin HS'in olumsuz etkisinin düzeltilmesinde katk1 sağlayabileceği kanaatine varılmıştır.

Anahtar sözcükler: Broyler, 1sı stresi, kekik esansiyel yağı, performans, vitamin

\section{Introduction}

The poultry sector is the fastest growing sub-sector in the livestock industry in Turkey. According to official data, the total number of slaughtered broilers in Turkey was 1.2 billion, and broiler meat production was 2.1 million tons in 2018 year (38). Thus, the average 
productivity per broiler increased to $1.75 \mathrm{~kg}(2.1$ million tons of meat/1.2 billion broilers). However, there are still several genetic and environmental barriers to increase the production and productivity in poultry. The productivity of chicken crucially depends on several environmental factors such as feed, management, nutritional factors, feeding conditions, and climate. Therefore, it is necessary to ensure the optimum ambient temperature in poultry production, which varies according to the breeding purpose and age of the animals. For example, the optimum ambient temperature, which is $34-35^{\circ} \mathrm{C}$ for $1-2$ day old commercial broiler flocks, should be reduced approximately $2^{\circ} \mathrm{C}$ per week (2). Otherwise, broilers are affected very quickly by adverse conditions and immediately yield losses occur. In this sense, different alternatives are being studied in order to guide the producers, offer options and provide support in their decisions. Because of the high costs of heat stress recommendations for poultry houses, the ventilation and cooling systems can be applied in large commercial enterprises. However, in the case of small producers, lowcost nutrition manipulations are the universal approach (24). One of these nutritional strategies is the use of essential oils in diet. Essential oils support live weight gain (LWG), reduce the development of pathogen microorganisms in the intestine, and have antioxidant effects. In the previous studies, it has been reported that the combined use of some vitamins may be advantageous compared to use individually, and new studies are required in this regard (29). Heat stress causes severe economic losses in animal production and the poultry sector worldwide (33). In recent years, diet-based measures to combat heat stress have become an important research area. When global warming is taken into consideration, studies on heat stress gain more sense.

Feed intake (FI) and LWG of broilers exposed to heat stress have been reported to be lower than broilers raised under thermoneutral $(\mathrm{TN})$ conditions $(10,14)$. One of the significant reasons for heat stress-induced poor performance in poultry is the oxidative stress due to the increasing lipid hydroperoxide level, total oxidant capacity, and oxidative stress index (7). Thyme (Origanum vulgare L.) is an aromatic plant that has been reported to have a high antioxidant capacity both in fresh and dry forms $(8,27)$. On the other hand, Vit A (retinol) plays a crucial role in the repair of tissues and the development of new cells. Vitamin A has antioxidant properties, and plays a vital role in the utilization of proteins, and proteins cannot be used efficiently in its deficiency (31).

Although Vit $\mathrm{C}$ is synthesized endogenously in poultry, it is thought to be insufficient for physiological demands, especially during certain environmental conditions such as heat stress. In such conditions, Vit C (ascorbic acid) supplementation has been reported to be beneficial to poultry (1) and can reverse the adverse effects of heat stress on LW, LWG, FI, and feed conversion ratio (FCR) in broilers (13). Similarly, Vit E supplementation can help to reduce the heat stress in poultry $(11,14)$, and removes free radicals with antioxidant properties and prevents lipid peroxidation (31).

Although studies are investigating the effect of TEO or some vitamins, especially Vit E, on reducing the effect of heat stress, limited studies are investigating the effect of TEO in combination with vitamins $\mathrm{A}, \mathrm{E}$ and $\mathrm{C}$. Considering the advantages of TEO and some vitamins especially with antioxidant properties mentioned previously $(11,13,31)$, the present study was conducted to investigate the potential impact of dietary supplemental TEO and vitamins (C, E, A) alone or in combination, as an anti-stress agents against the negative effects of heat stress on growth performance, carcass quality, malondialdehyde (MDA) and 8-Hydroxydeoxyguanosine (8-OHdG) levels in broilers exposed to heat stress during the finishing period (21-41 days old).

\section{Material and Methods}

The study was performed with the permission of the Erciyes University Animal Experimentation Local Ethics Committee (13/53). In this study, a total of 300 male Ross308 broiler chicks were used. The temperature on day one was set at $32 \pm 2^{\circ} \mathrm{C}$ and gradually reduced to $28 \pm 2^{\circ} \mathrm{C}$ on day 21 . Within this period, a commercial starter diet (\%23 $\mathrm{HP}$ and $3200 \mathrm{kcal} / \mathrm{kg} \mathrm{ME}$ ) was provided to animals in all groups. The chicks with similar live weights $(\mathrm{P}>0.05)$ were equally divided into six groups with five replicates on the $21^{\text {st }}$ day. The ambient temperature was set to $22^{\circ} \mathrm{C}$ in thermoneutral control (TNC) groups, to $34^{\circ} \mathrm{C}$ between $08: 00-17:{ }^{00}$ (nine hours) and $22^{\circ} \mathrm{C}$ between $17::^{00}-08:^{00}$ (15 hours) in the heat stress (HS) groups. A thermostatcontrolled radiator and split air conditioner were used to ensure the homogenous temperature in the room. During the study, the temperature and humidity in the room were continuously controlled by thermometer and hygrometer. Rough wood shavings were used as litter. A 23 hour of light and 1 hour of darkness lighting schedule was applied during the trial. All animals were allowed ad libitum access to feed and water.

The animals were fed with commercial broiler finishing diet (20\% $\mathrm{HP}$ and $3200 \mathrm{kcal} / \mathrm{kg} \mathrm{ME}$ ) from day 21 to 41 (9). A $300 \mathrm{mg} / \mathrm{kg}$ thyme essential oil (TEO) or combinations of TEO and vitamin A, C and E were added to the diets of the heat stress (HS) groups (except HSC). The experimental groups were designed as follows: 1: Thermoneutral control (TNC, basal diet, $22^{\circ} \mathrm{C}$ ), 2: Heat stress control (HSC, basal diet, $34^{\circ} \mathrm{C}$ ), 3: TEO (basal diet $+300 \mathrm{mg} / \mathrm{kg}$ TEO, $34^{\circ} \mathrm{C}$ ), 4 : TEO + Vit C (basal diet + 
$300 \mathrm{mg} / \mathrm{kg}$ TEO $+250 \mathrm{mg} / \mathrm{kg}$ Vit C, $\left.34^{\circ} \mathrm{C}\right), 5: \mathrm{TEO}+\mathrm{Vit}$ $\mathrm{E}$ (basal diet $+300 \mathrm{mg} / \mathrm{kg} \mathrm{TEO}+250 \mathrm{mg} / \mathrm{kg} \mathrm{Vit} \mathrm{E,} 34^{\circ} \mathrm{C}$ ) and 6: TEO + Vit A (basal diet + $300 \mathrm{mg} / \mathrm{kg}$ TEO + 15000 $\mathrm{IU} / \mathrm{kg}$ Vit $\left.\mathrm{A}, 34^{\circ} \mathrm{C}\right)$. Nutrient composition of the diet was calculated according to NRC (9) and given in Table 1.

Table 1. Ingredients and calculated chemical composition of basal diet.

\begin{tabular}{|c|c|}
\hline Feeds & Quantity, \% \\
\hline Corn & 32.00 \\
\hline Corn bran & 15.00 \\
\hline Wheat & 11.30 \\
\hline Soy bean meal $(46 \% \mathrm{CP})$ & 11.00 \\
\hline Sunflower meal (36\% CP) & 8.30 \\
\hline Vegetable oil & 6.50 \\
\hline Wheat bran & 5.40 \\
\hline Corn gluten meal & 4.60 \\
\hline Meat- bone meal & 3.00 \\
\hline Limestone & 1.60 \\
\hline Salt & 0.25 \\
\hline Vitamine -mineral Premix ${ }^{1}$ & 0.25 \\
\hline Lysine & 0.44 \\
\hline Methionine & 0.16 \\
\hline Phytase enzyme $^{2}$ & 0.10 \\
\hline Enzyme mixture $^{3}$ & 0.10 \\
\hline \multicolumn{2}{|c|}{ Calculated chemical composition } \\
\hline Dry matter, $\%$ & 88.86 \\
\hline Crude protein, $\%$ & 20.00 \\
\hline Crude fat, $\%$ & 9.00 \\
\hline Crude fibre, $\%$ & 5.40 \\
\hline Calcium, \% & 1.08 \\
\hline Available phosphorus, $\%$ & 0.45 \\
\hline Lysine, $\%$ & 1.30 \\
\hline Methionine, $\%$ & 0.50 \\
\hline Metabolizable energy, $\mathrm{kcal} / \mathrm{kg}$ & 3172 \\
\hline
\end{tabular}

1: One kilogram of vitamin-mineral premix: Vitamin A, 15.000 IU; Vitamin D3, 2000 IU; Vitamin E, $40.0 \mathrm{mg}$; Vitamin K, 5.0 $\mathrm{mg}$; Vitamin B1(thiamine), $3.0 \mathrm{mg}$; Vitamin B2 (riboflavin, 6.0 mg; Vitamin B6, $5.0 \mathrm{mg}$; Vitamin B12, $0.03 \mathrm{mg}$; Niacin, 30.0 $\mathrm{mg}$; Biotin, 0,1 mg; calcium D-pantothenate, $12 \mathrm{mg}$; Folic acid, $1.0 \mathrm{mg}$; choline chloride, $400 \mathrm{mg}$; manganese, $80.0 \mathrm{mg}$; iron, 35.0 $\mathrm{mg}$; zinc, $50.0 \mathrm{mg}$; copper, $5.0 \mathrm{mg}$; iodine, $2.0 \mathrm{mg}$; cobalt, 0.4 $\mathrm{mg}$; selenium, $0.15 \mathrm{mg}$. 2: kg; $5000 \mathrm{FTU} / \mathrm{kg}$ of phytase enzyme. 3: $\mathrm{kg} ; \beta$-glucanase $9000 / \mathrm{BGU} / \mathrm{g}$, Xylanase $40000 \mathrm{XU} / \mathrm{G}$, mannanase $1000 \mathrm{U} / \mathrm{g}$, cellulase $50 \mathrm{FPU} / \mathrm{g}$, pectinases 50 PGLU/g.

In this study, individual LW and group FI measurements of broilers were performed on days 21, 31, and 41 with $2 \mathrm{~g}$ precision scales (Densi DS-20, serial number: 6673) and then daily LWG and FCR were calculated. The mortality rate during the study was considered in the calculation of the mean FI. The average daily FI per animal was determined by measuring the consumed feed between two weightings. The amount of feed consumed was divided by the number of days of feeding, and then by the number of animals belonging to that group.

The FCR for 10 days (21-31 and 31-41 days) was calculated by dividing the total amount of FI between the two weighing by the total LWG from the beginning of the experiment. All groups were controlled daily, and the number of dead animals was recorded, and the mortality rate was determined.

At the end of the treatment (on day 41), four chicks from each replicate whose weights were representative of the average weight per treatment were selected, slaughtered, de-feathered, and eviscerated following standard commercial procedures for determining the carcass traits. Cold carcass weights were determined after $18 \mathrm{~h}$ at $4^{\circ} \mathrm{C}$ in a refrigerator. Carcass part yields (\%) were calculated by the following formula: (carcass part weight/carcass weight) $* 100$.

Blood samples of 12 broilers from each group were collected from $V$. brachialis in sterile tubes without anticoagulant and with anticoagulant at the end of the experiment (day 41). After clotting for one hour at room temperature $\left(24^{\circ} \mathrm{C}\right)$ and centrifugation at $1300 \times \mathrm{g}$ for 10 minutes at room temperature, sera and plasma were carefully separated and stored at $-20^{\circ} \mathrm{C}$ until analysis. Serum glucose levels were determined by spectrophotometer (Shimadzu 1208 UV/VIS, Japan) with commercial kits (Biolabo, France). Plasma MDA (TBARS ELISA Kit, Cayman, USA, Cat. no 10009055) and plasma 8-OHdG (Northwest Life Science Specialist and LLC, Washington, Code: NWK 8-OHdG 02) levels were determined by enzyme-linked immunosorbent assay (ELISA) according to the instruction of manufacturers of commercially available kits using the Quant (Bio-Tek) ELISA reader.

In the economic analysis, the calculation was performed based on the total LWG on a group basis during the trial (20 days). Thus, net profits were calculated by subtracting production costs from total income (sales revenue). In this calculation, chicken price determined as $1.70 \$ / \mathrm{kg}$ and feed price considered as $0.35 \$ / \mathrm{kg}$ in 2019 prices. Feed expenses were evaluated as $70 \%$ of the total expenses and the remaining $30 \%$ as other expenses. The cost of TEO was $100 \$ / \mathrm{kg}$ and the prices of Vit A, Vit E and Vit C were $120 \$ / \mathrm{kg}, 7 \$ / \mathrm{kg}$ and $6.50 \$ / \mathrm{kg}$ respectively.

Statistical analysis: The experiment was arranged according to a completely randomized design, and obtained data were analyzed by SPSS. The q-q plot, histogram, and the Shapiro-Wilk test were used to determine the suitability of the data for normal distribution. The differences between groups were determined with a one-way analysis of variance (ANOVA) and the Kruskal-Wallis test. The homogeneity 
of variances was determined by the Levene test. When the $F$ values were significant, Duncan's multiple range test was performed. The $\mathrm{P}$ values $<0.05$ were considered significant. All data were expressed as means \pm SEM (32).

\section{Results}

At the beginning of the study (day $21^{\text {st }}$ ), animals with similar live weights were assigned into the groups after weighting, and there was no significant difference between groups.

In the study, LW of the animals was lower in all HS groups compared to the TNC group. The decrease in LW of the broilers in the HSC group was numerically low on the $31^{\text {st }}$ day but significant on the $41^{\text {st }}$ day of the experiment $(\mathrm{P}<0.01)$. The highest daily $\mathrm{LWG}$ was in the TNC group, and the lowest daily LWG was in the HSC group for the first 10 days (21-31 days) of the study.

In the first 10 days of the study, LWG was significantly lower in the HSC, TEO, TEO + Vit A groups than in the TNC group, whereas in the TEO + Vit C and $\mathrm{TEO}+\mathrm{Vit} \mathrm{E}$ groups, the increase in LW was found to be higher than other heat stress groups and close to the TNC group. On the other hand, no significant difference was observed between the groups in terms of daily LWG between $31-41^{\text {st }}$ days. Overall, daily LWG in the HSC and treatment groups were significantly lower than the TNC group ( $\mathrm{P}<0.05$; Table 2). Considering the total FI, the highest value was observed in the TNC group, while the lowest value was found in the HSC group $(\mathrm{P}<0.05)$. Feed intake was significantly reduced in all heat stress groups, except TEO + Vit E, which was not significantly different from the TNC group. There was no significant difference among groups in FCR. The differences in mortality rate were not significant (Table 2).

When the groups were evaluated from the economic point of view, the highest total LW was found in the TNC group with $56.3 \mathrm{~kg}$ and the lowest in the TEO + Vit E group with $46.0 \mathrm{~kg}$. Total production cost, sales revenue, and net profit were again the highest in the TNC group, while the lowest production cost was in the TEO + Vit E group with $33.17 \$$ among the treatment groups. The lowest profitability was found in the TEO + Vit A group (Table 3).

The HS and the additives used in the study did not have any significant effects on serum glucose, plasma MDA, and plasma $8 \mathrm{OHdG}$ variables (Table 4).

At the end of the study, no significant differences were observed between the groups in terms of hot and cold carcass yield, thigh, breast, wing, neck, liver, and heart rate (Table 5).

Table 2. Effects of thyme essential oil and vitamin combinations on performance parameters in broilers exposed to heat stress (Mean \pm SEM).

\begin{tabular}{|c|c|c|c|c|c|c|c|}
\hline \multirow[t]{2}{*}{ Parameters } & \multicolumn{7}{|c|}{ Groups } \\
\hline & TNC & HSC & TEO & TEO+Vit C & TEO+Vit E & TEO+Vit A & $\mathbf{P}$ \\
\hline \multicolumn{8}{|l|}{$\mathbf{L W}, \mathbf{g}$} \\
\hline $21^{\text {st }}$ day, initial & $851.9 \pm 12.8$ & $854.2 \pm 14.8$ & $866.9 \pm 13.7$ & $846.0 \pm 11.4$ & $860.0 \pm 11.5$ & $866.0 \pm 11.4$ & 0.861 \\
\hline $31^{\text {st }}$ day & $1447.1 \pm 26.4$ & $1339.5 \pm 28.9$ & $1381.1 \pm 31.4$ & $1371.2 \pm 17.8$ & $1396.4 \pm 27.1$ & $1354.4 \pm 27.2$ & 0.082 \\
\hline $41^{\text {st }}$ day & $1978.3 \pm 42.3^{\mathrm{a}}$ & $1821.3 \pm 42.5^{b}$ & $1841.0 \pm 37.3^{\mathrm{b}}$ & $1819.6 \pm 25.2^{\mathrm{b}}$ & $1798.4 \pm 40.9^{b}$ & $1797.2 \pm 33.3^{\mathrm{b}}$ & 0.006 \\
\hline \multicolumn{8}{|c|}{ LWG, g/day/broiler } \\
\hline $21-31$ & $59.5 \pm 1.9^{\mathrm{a}}$ & $48.5 \pm 1.3^{\mathrm{b}}$ & $51.4 \pm 4.1^{\mathrm{b}}$ & $52.5 \pm 0.9^{\mathrm{ab}}$ & $53.5 \pm 2.5^{\mathrm{ab}}$ & $48.8 \pm 2.5^{\mathrm{b}}$ & 0.049 \\
\hline $31-41$ & $53.1 \pm 4.7$ & $47.9 \pm 2.3$ & $45.9 \pm 3.5$ & $44.6 \pm 3.4$ & $40.1 \pm 2.1$ & $44.2 \pm 2.4$ & 0.161 \\
\hline Total & $56.3 \pm 3.2^{\mathrm{a}}$ & $48.2 \pm 1.2^{\mathrm{b}}$ & $48.7 \pm 2.5^{\mathrm{b}}$ & $48.6 \pm 1.5^{\mathrm{b}}$ & $46.8 \pm 1.9^{\mathrm{b}}$ & $46.5 \pm 1.4^{\mathrm{b}}$ & 0.038 \\
\hline \multicolumn{8}{|l|}{ FI, g/day/broiler } \\
\hline $21-31$ & $80.9 \pm 2.5$ & $67.7 \pm 1.9$ & $71.5 \pm 7.3$ & $72.6 \pm 2.2$ & $78.7 \pm 3.4$ & $70.8 \pm 3.3$ & 0.184 \\
\hline $31-41$ & $161.1 \pm 6.1$ & $144.4 \pm 3.8$ & $145.9 \pm 7.1$ & $144.3 \pm 2.6$ & $146.9 \pm 3.8$ & $146.0 \pm 3.2$ & 0.137 \\
\hline Total & $121.0 \pm 3.8^{\mathrm{a}}$ & $104.7 \pm 1.8^{\mathrm{b}}$ & $108.7 \pm 5.6^{\mathrm{b}}$ & $108.2 \pm 1.3^{\mathrm{b}}$ & $112.3 \pm 3.8^{\mathrm{ab}}$ & $108.4 \pm 2.5^{\mathrm{b}}$ & 0.046 \\
\hline \multicolumn{8}{|l|}{ FCR, g FI/ g LWG } \\
\hline $21-31$ & $1.36 \pm 0.04$ & $1.43 \pm 0.04$ & $1.38 \pm 0.03$ & $1.38 \pm 0.02$ & $1.47 \pm 0.02$ & $1.45 \pm 0.03$ & 0.206 \\
\hline $31-41$ & $3.10 \pm 0.18$ & $3.05 \pm 0.15$ & $3.22 \pm 0.18$ & $3.29 \pm 0.22$ & $3.69 \pm 0.20$ & $3.32 \pm 0.13$ & 0.215 \\
\hline Total & $2.16 \pm 0.07$ & $2.20 \pm 0.05$ & $2.23 \pm 0.04$ & $2.23 \pm 0.06$ & $2.40 \pm 0.08$ & $2.33 \pm 0.03$ & 0.124 \\
\hline Mortality rate, \% & 0.0 & 4.0 & 0.0 & 4.0 & 2.0 & 0.0 & 0.243 \\
\hline
\end{tabular}

a,b; Means on the same row differently superscripted are significantly different $(\mathrm{P}<0.05)$. TNC (Thermoneutral control group, basal diet, $22^{\circ} \mathrm{C}$ ), HSC (Heat stress control, basal diet, $34^{\circ} \mathrm{C}$ ), TEO (basal diet $+300 \mathrm{mg} / \mathrm{kg} \mathrm{TEO}, 34^{\circ} \mathrm{C}$ ), TEO+Vit C (basal diet $+300 \mathrm{mg} / \mathrm{kg}$ $\mathrm{TEO}+250 \mathrm{mg} / \mathrm{kg}$ Vit C, $34^{\circ} \mathrm{C}$ ), TEO+Vit E (basal diet $+300 \mathrm{mg} / \mathrm{kg}$ TEO $+250 \mathrm{mg} / \mathrm{kg} \mathrm{Vit} \mathrm{E,} 34^{\circ} \mathrm{C}$ ), TEO+Vit A (basal diet $+300 \mathrm{mg} / \mathrm{kg}$ $\mathrm{TEO}+15000 \mathrm{IU} / \mathrm{kg}$ Vit A, $\left.34^{\circ} \mathrm{C}\right), \mathrm{n}=5$.

LW: live weight; LWG: live weight gain; FI: feed intake; FCR: feed conversion ratio 
Table 3. Comparison of treatments in terms of economic parameters* (Mean $\pm \mathrm{SEM}$ ).

\begin{tabular}{lccccccc}
\hline \multirow{2}{*}{ Parameters } & \multicolumn{7}{c}{ Groups } \\
\cline { 2 - 8 } & TNC & HSC & TEO & TEO+Vit C & TEO+Vit E & TEO+Vit A & P \\
\hline Total gained LW, kg & $56.32 \pm 3.27^{\mathrm{a}}$ & $48.22 \pm 1.29^{\mathrm{b}}$ & $48.70 \pm 2.56^{\mathrm{b}}$ & $48.60 \pm 1.57^{\mathrm{b}}$ & $46.85 \pm 1.96^{\mathrm{b}}$ & $46.56 \pm 1.42^{\mathrm{b}}$ & 0.038 \\
Total production cost $(\$)$ & $42.14 \pm 2.44^{\mathrm{a}}$ & $34.76 \pm 0.93^{\mathrm{b}}$ & $37.97 \pm 2.00^{\mathrm{ab}}$ & $37.41 \pm 1.20^{\mathrm{ab}}$ & $33.17 \pm 1.39^{\mathrm{b}}$ & $37.64 \pm 1.15^{\mathrm{ab}}$ & 0.014 \\
Total income (\$) & $95.46 \pm 1.22^{\mathrm{a}}$ & $78.68 \pm 0.49^{\mathrm{bc}}$ & $82.56 \pm 1.81^{\mathrm{b}}$ & $79.20 \pm 0.54^{\mathrm{bc}}$ & $77.97 \pm 1.54^{\mathrm{c}}$ & $78.98 \pm 1.73^{\mathrm{bc}}$ & 0.000 \\
Net profit (\$group) & $53.32 \pm 1.22^{\mathrm{a}}$ & $43.92 \pm 0.49^{\mathrm{b}}$ & $44.59 \pm 1.81^{\mathrm{b}}$ & $41.80 \pm 0.54^{\mathrm{b}}$ & $44.80 \pm 1.54^{\mathrm{b}}$ & $41.34 \pm 1.73^{\mathrm{b}}$ & 0.000 \\
Net profit (\$/broiler) & $1.07 \pm 0.02^{\mathrm{a}}$ & $0.88 \pm 0.02^{\mathrm{b}}$ & $0.90 \pm 0.03^{\mathrm{b}}$ & $0.83 \pm 0.02^{\mathrm{b}}$ & $0.90 \pm 0.03^{\mathrm{b}}$ & $0.83 \pm 0.03^{\mathrm{b}}$ & 0.000 \\
\hline
\end{tabular}

*Calculations were made on a group basis considering mortality rates. ${ }^{\text {a-c }}$; Means on the same row differently superscripted are significantly different $(\mathrm{P}<0.05)$.

TNC (Thermoneutral control group, basal diet, $22^{\circ} \mathrm{C}$ ), $\mathrm{HSC}$ (Heat stress control, basal diet, $34^{\circ} \mathrm{C}$ ), TEO (basal diet $+300 \mathrm{mg} / \mathrm{kg}$ TEO, $34^{\circ} \mathrm{C}$ ), TEO+Vit C (basal diet $+300 \mathrm{mg} / \mathrm{kg}$ TEO $+250 \mathrm{mg} / \mathrm{kg}$ Vit C, $34^{\circ} \mathrm{C}$ ), TEO+Vit E (basal diet+300mg $/ \mathrm{kg}$ TEO $+250 \mathrm{mg} / \mathrm{kg} \mathrm{Vit} \mathrm{E}$, $34^{\circ} \mathrm{C}$ ), TEO+Vit A (basal diet $+300 \mathrm{mg} / \mathrm{kg}$ TEO $+15000 \mathrm{IU} / \mathrm{kg}$ Vit $\left.\mathrm{A}, 34^{\circ} \mathrm{C}\right), \mathrm{n}=5$. LW: live weight

Table 4. Comparison of serum glucose, plasma MDA and 8-OHdG variables among groups (Mean \pm SEM)

\begin{tabular}{|c|c|c|c|c|c|c|c|}
\hline \multirow[b]{2}{*}{ Parameters } & \multicolumn{6}{|c|}{ Groups } & \multirow{2}{*}{$\begin{array}{c}\mathbf{P} \\
\text { (Kruskal } \\
\text { Wallis) }\end{array}$} \\
\hline & TNC & HSC & TEO & TEO+Vit C & TEO+Vit E & TEO+Vit A & \\
\hline $\begin{array}{l}\text { Serum glucose, } \\
\mathrm{mg} / \mathrm{dL}\end{array}$ & $263.86 \pm 18.91$ & $246.51 \pm 12.34$ & $248.04 \pm 10.41$ & $247.54 \pm 23.99$ & $247.92 \pm 16.31$ & $274.53 \pm 10.25$ & 0.757 \\
\hline $\begin{array}{l}\text { Plasma MDA, } \\
\mu \mathrm{mol} / \mathrm{L}\end{array}$ & $3.38 \pm 0.24$ & $5.23 \pm 0.82$ & $3.77 \pm 0.18$ & $3.29 \pm 0.17$ & $4.29 \pm 0.74$ & $3.22 \pm 0.14$ & 0.246 \\
\hline $\begin{array}{l}\text { Plasma 8- OHdG, } \\
\mathrm{ng} / \mathrm{mL}\end{array}$ & $3.92 \pm 0.58$ & $4.00 \pm 0.62$ & $4.27 \pm 0.63$ & $3.94 \pm 0.59$ & $4.19 \pm 0.58$ & $4.94 \pm 0.36$ & 0.787 \\
\hline
\end{tabular}

TNC (Thermoneutral control group, basal diet, $22^{\circ} \mathrm{C}$ ), HSC (Heat stress control, basal diet, $34^{\circ} \mathrm{C}$ ), TEO (basal diet $+300 \mathrm{mg} / \mathrm{kg}$ TEO, $34^{\circ} \mathrm{C}$ ), TEO+Vit C (basal diet $+300 \mathrm{mg} / \mathrm{kg}$ TEO $+250 \mathrm{mg} / \mathrm{kg} \mathrm{Vit} \mathrm{C,} 34^{\circ} \mathrm{C}$ ), TEO+Vit E (basal diet $+300 \mathrm{mg} / \mathrm{kg}$ TEO+250mg $/ \mathrm{kg} \mathrm{Vit} \mathrm{E}$, $34^{\circ} \mathrm{C}$ ), TEO+Vit A (basal diet $+300 \mathrm{mg} / \mathrm{kg}$ TEO+15000IU $/ \mathrm{kg}$ Vit A, $34^{\circ} \mathrm{C}$ ), $\mathrm{n}=12$. MDA: malondialdehyde; 8- OHdG: 8Hydroxydeoxyguanosine

Table 5. Effects of thyme essential oil and vitamin combinations on carcass and organ traits in broilers exposed to heat stress $(\mathrm{Mean} \pm \mathrm{SEM})$

\begin{tabular}{|c|c|c|c|c|c|c|c|}
\hline \multirow{2}{*}{ Parameters } & \multicolumn{6}{|c|}{ Groups } & \multirow{2}{*}{$\begin{array}{c}P \\
\text { (Anova) }\end{array}$} \\
\hline & TNC & HSC & TEO & TEO+Vit C & TEO+Vit E & TEO+Vit A & \\
\hline Hot carcass, g & $1423.20 \pm 37.43$ & $1329.20 \pm 36.02$ & $1272.40 \pm 39.74$ & $1330.00 \pm 37.78$ & $1322.00 \pm 31.39$ & $1338.60 \pm 35.17$ & 0.127 \\
\hline Cold carcass, $\mathrm{g}$ & $1374.00 \pm 36.89$ & $1286.50 \pm 34.30$ & $1222.90 \pm 39.17$ & $1287.30 \pm 37.40$ & $1281.30 \pm 31.13$ & $1281.00 \pm 37.61$ & 0.124 \\
\hline Shrinkage, \% & $3.47 \pm 0.16$ & $3.20 \pm 0.16$ & $3.91 \pm 0.24$ & $3.23 \pm 0.14$ & $3.09 \pm 0.18$ & $3.85 \pm 0.44$ & 0.083 \\
\hline Thigh, \% & $38.24 \pm 0.52$ & $39.57 \pm 0.63$ & $38.29 \pm 0.49$ & $38.60 \pm 0.43$ & $40.49 \pm 1.15$ & $39.01 \pm 0.61$ & 0.154 \\
\hline Breast, $\%$ & $42.92 \pm 0.66$ & $41.42 \pm 0.59$ & $41.74 \pm 0.61$ & $42.83 \pm 0.65$ & $41.50 \pm 0.88$ & $40.53 \pm 0.95$ & 0.192 \\
\hline Wing, $\%$ & $10.64 \pm 0.25$ & $11.30 \pm 0.24$ & $10.98 \pm 0.26$ & $10.43 \pm 0.23$ & $10.44 \pm 0.26$ & $10.53 \pm 0.28$ & 0.111 \\
\hline Neck, $\%$ & $4.50 \pm 0.11$ & $4.32 \pm 0.17$ & $4.82 \pm 0.16$ & $4.69 \pm 0.18$ & $4.94 \pm 0.22$ & $5.00 \pm 0.18$ & 0.070 \\
\hline Liver, $\%$ & $2.98 \pm 0.06$ & $2.98 \pm 0.07$ & $3.08 \pm 0.15$ & $3.05 \pm 0.12$ & $2.94 \pm .072$ & $2.93 \pm 0.07$ & 0.878 \\
\hline Heart, \% & $0.65 \pm 0.02$ & $0.59 \pm 0.02$ & $0.64 \pm 0.02$ & $0.59 \pm 0.02$ & $0.62 \pm 0.02$ & $0.59 \pm 0.02$ & 0.262 \\
\hline
\end{tabular}

TNC (Thermoneutral control group, basal diet, $22^{\circ} \mathrm{C}$ ), HSC (Heat stress control, basal diet, $34^{\circ} \mathrm{C}$ ), TEO (basal diet $+300 \mathrm{mg} / \mathrm{kg} \mathrm{TEO}$, $34^{\circ} \mathrm{C}$ ), TEO+Vit C (basal diet $+300 \mathrm{mg} / \mathrm{kg}$ TEO $+250 \mathrm{mg} / \mathrm{kg}$ Vit C, $34^{\circ} \mathrm{C}$ ), TEO+Vit E (basal diet $+300 \mathrm{mg} / \mathrm{kg} \mathrm{TEO}+250 \mathrm{mg} / \mathrm{kg} \mathrm{Vit} \mathrm{E,}$ $34^{\circ} \mathrm{C}$ ), TEO+Vit A (basal diet $+300 \mathrm{mg} / \mathrm{kg}$ TEO $+15000 \mathrm{IU} / \mathrm{kg}$ Vit A, $34^{\circ} \mathrm{C}$ ), $\mathrm{n}=20$.

\section{Discussion and Conclusion}

The temperature in the poultry house is one of the most critical factors affecting animal performance in poultry production, and the optimum ambient temperature for poultry is $15-25^{\circ} \mathrm{C}(20)$. It has been reported that growth performance is adversely affected when the environmental temperature exceeds $25^{\circ} \mathrm{C}(20,26)$. In this study, the decrease in LW, daily LWG, and FI in the groups exposed to HS was found to be consistent with the results of previous studies $(3,4,6)$. The negative effect of 
HS on growth performance has been attributed to reduced FI, degradation of digestion and metabolism, and reduction in the size and secretion of the thyroid gland (18, 24). Chronic HS influences the peripheral thermal receptors, which transmit nerve impulses that suppress the activity of the appetite center in the hypothalamus causing the FI reduction. Therefore, fewer nutrients and molecules become available for enzymatic activities and synthesis, hormone production, and heat generation (6). In the present study, a significant difference among the groups in terms of FCR confirms the results of Tatlı Seven et al. (36) and Stilborn et al. (34).

Disruption of the balance between free radicals and the biological antioxidant system of the living organism results in a physiological condition called oxidative stress. Some factors, such as high ambient temperatures, cause oxidative stress in broilers and reduce the activity and concentration of enzymatic and non-enzymatic antioxidants (5). The depressed concentration of nonenzymatic antioxidants, such as vitamin E, C, and A, was associated with increased lipid peroxidation both in the tissues and plasma with consequent damage to cell membranes (30). It is reported that different strategies can be applied to minimize or prevent the negative effects of chronic HS (12). The cheapest and most straightforward application of these strategies is to use feed additives (6, 30 ). In the present study, in order to reduce the negative effects of HS on growth in broilers, the TEO and combinations of TEO with non-enzymatic antioxidants Vitamin A, C, and E were supplemented into the broiler diet.

The lack of a significant difference in growth performance in the TEO groups was in parallel with the results of previous studies conducted by Karsli and Dönmez (20) and Montazeri et al. (23) who reported that plant extracts or essential oils were not useful in reducing the negative impact of HS. On the other hand, in the first half of the study, although not statistically significant, higher daily LWG in the groups supplemented with the TEO together with Vit $\mathrm{C}$ and Vit $\mathrm{E}$ indicated that supplements (vitamins, plant extracts, etc.) might be useful in preventing the negative effect of HS (15). However, when the overall growth performance was evaluated at the end of the study, unlike the findings of several previous studies $(21,22,25,37)$, it was found that supplements are not useful to reduce or eliminate the negative effect of HS (28). Similarly, Niu et al. (26) and Ghazi Harsini et al. (14) reported that the supplementation of Vit $\mathrm{E}$ in broilers exposed to HS did not affect performance. Some researchers $(30,35)$ reported that several factors might be responsible for the efficacy of dietary supplementations in broiler chickens under HS, including quantity and duration of supplementations, diet, age of birds, and the level of stress.
Several studies reported the active organ weight decreases due to reduced glucose transport because of diminished nutrient intake and reduced nutrient supply for organs development due to increased corticosterone levels in broilers exposed to HS $(16,35)$. However, in this study, it was found that the heart and liver weights were not different between HSC and TNC groups. Similar to our findings, Hajati et al. (17) reported no differences in carcass, leg and breast yield, in broilers reared under thermoneutral and HS conditions (17). In the present study, no significant effects of supplements were determined on carcass quality and carcass parts.

It has been reported that total serum antioxidants, which are natural preservatives in response to oxidative stress, are increased in response to increased temperature. Conversely, HS did not significantly increase the serum antioxidant activity of broilers in the present study. Although the exact reason for the lack influence of HS on serum antioxidant activity in broilers is still unclear, the acclimatization of birds to chronic HS seemed to improve their heat tolerance (4), resulting in less alteration of metabolism. This acclimatization may alleviate oxidative stress (4), thus preventing further increased antioxidant activity in the serum of HS birds. Our present data show that neither HS nor additive supplementations had changed any of the plasma $8 \mathrm{OHdG}$ and glucose levels of birds. Similarly, İmik et al. (19) reported that HS and Vit C supplementation did not affect serum glucose levels.

Economically, HS was reduced the profitability of treatment groups. However, because of their high costs, there was no positive effect of the supplements used in the study on profitability.

Considering the significantly lower LWG in HSC, TEO, TEO + Vit A groups compared to TNC whereas no significant differences between TEO + Vit E group and TNC, and also the numerical increase in FI in the TEO + Vit E group compared to the HSC and other treatment groups as well as numerical approach to the TNC group in the first half of the study, it was concluded that the combination of TEO with Vit E might be useful, albeit partially, to reduce the negative effect of HS. However, in order to reduce the adverse effects of HS, further studies are needed to determine the additives or doses to be used.

\section{Financial Support}

This manuscript has been supported by Erciyes University Scientific Research Project Unit (TOA-20134491).

\section{Ethical Statement}

This study was approved by the Erciyes University Animal Experimentation Local Ethics Committee (13/53). 


\section{Conflict of Interest}

The authors declared that there is no conflict of interest.

\section{References}

1. Abudabos AM, Al-Owaimer AN, Hussein EOS, et al (2018): Effect of natural vitamin c on performance and certain haemato-biochemical values in broiler chickens exposed to heat stress. Pak J Zool, 50, 951-955.

2. Aksoy F (1999): Tavuk yetiştiriciliği. Şahin Matbaası, Ankara.

3. Akşit M, Yalçin S, Ozkan S, et al (2006): Effects of temperature during rearing and crating on stress parameters and meat quality of broilers. Poult Sci, 85, 1867-1874.

4. Al-Fataftah ARA, Abu-Dieyeh ZHM (2007): Effect of chronic heat stress on broiler performance in Jordan. Int $\mathrm{J}$ Poult Sci, 6, 64-70.

5. Altan Ö, Pabuçcuoğlu A, Altan A, et al (2003): Effect of heat stress on oxidative stress, lipid peroxidation and some stress parameters in broilers. Br Poult Sci, 44, 545-550.

6. Attia YA, Al-Harthi MA, El-Shafey AS, et al (2017): Enhancing tolerance of broiler chickens to heat stress by supplementation with vitamin $E$, vitamin $C$ and/or probiotics. Ann Anim Sci, 17, 1155-1169.

7. Aydilek N, Cadirci S, Can A, et al (2012): Effect of free choice feeding as to protein levels on oxidative status in the broilers exposed to heat stress. Kafkas Univ Vet Fak Derg, 18, 1049-1054.

8. Capecka E, Mareczek A, Leja M (2005): Antioxidant activity of fresh and dry herbs of some Lamiaceae species. Food Chem, 93, 223-226.

9. Council National Research (1994): Nutrient Requirements of Poultry: Ninth Revised Edition. The National Academics Press, Washington, D.C., USA.

10. Daghir NJ (2009): Nutritional strategies to reduce heat stress in broilers and broiler breeders. Lohmann Inf, 44, 615.

11. Das S, Palai T, Mishra S, et al (2011): Nutrition in relation to diseases and heat stress in poultry. Vet World, 4, 429432.

12. Diarra SS, Tabuaciri P (2014): Feeding management of poultry in high environmental temperatures. Int J Poult Sci, 13, 657-661.

13. El-Habbak MM, El-Ghamry AA, El-Mallah GM, et al (2011): Influence of dietary vitamin $E$ and $C$ supplementation on performance and some metabolic response of broiler chicks subjected to heat stress. World Agr Sci, 7, 258-269.

14. Ghazi Harsini S, Habibiyan M, Moeini MM, et al (2012): Effects of dietary selenium, vitamin $E$, and their combination on growth, serum metabolites, and antioxidant defense system in skeletal muscle of broilers under heat stress. Biol Trace Elem Res, 148, 322-330.

15. Ghazi S, Amjadian T, Norouzi S (2015): Single and combined effects of vitamin $C$ and oregano essential oil in diet, on growth performance, and blood parameters of broiler chicks reared under heat stress condition. Int J Biometeorol, 59, 1019-1024.
16. Habibian M, Ghazi S, Moeini MM, et al (2014): Effects of dietary selenium and vitamin E on immune response and biological blood parameters of broilers reared under thermoneutral or heat stress conditions. Int J Biometeorol, 58, 741-752.

17. Hajati H, Hassanabadi A, Golian AG, et al (2015): The effect of grape seed extract and vitamin C feed supplements carcass characteristics, gut morphology and ileal microflora in broiler chickens exposed to chronic heat stress. Iran J Appl Anim Sci, 5, 155-165.

18. Hosseini-Vashan SJ, Golian A, Yaghobfar A (2016): Growth, immune, antioxidant, and bone responses of heat stress-exposed broilers fed diets supplemented with tomato pomace. Int J Biometeorol, 60, 1183-1192.

19. Imik H, Kaynar O, Ozkanlar S, et al (2013): Effects of vitamin $C$ and $\alpha$-lipoid acid dietary supplementations on metabolic adaptation of broilers to heat stress. Rev Méd Vét, 164, 52-59.

20. Karslı MA, Dönmez HH (2007): Effects of plant extract on growth performance and villi of the small bowel in heat stressed broiler. Atatürk Univ J Vet Sci, 2, 143-148.

21. Kutlu HR (2001): Influences of wet feeding and supplementation with ascorbic acid on performance and carcass composition of broiler chicks exposed to a high ambient temperature. Arch Anim Nutr, 54, 127-139.

22. Kutlu HR, Forbes JM (1993): Changes in growth and blood parameters in heat-stressed broiler chicks in response to dietary ascorbic acid. Livest Prod Sci, 36, 335350 .

23. Montazeri S, Jafari M, Khojasteh S (2014): The effect of powder and essential oil of savory medicinal plant (Satureja Hortensis) on performance and antioxidant status of broiler chicks under heat stress. Iran J Appl Anim Sci, 4, 573-577.

24. Naresh P, Rani UM, Kumar VM (2017): Efficacy evaluation of polyherbal antistress formulation and synthetic vitamin $C$ on broiler birds performance under physiological heat stress. The Pharma Innov Journal, 6, 1821.

25. Naseem S, Younus M, Anwar B, et al (2005): Effect of ascorbic acid and acetylsalicylic acid supplementation on performance of broiler chicks exposed to heat stress. Int $\mathbf{J}$ Poult Sci, 4, 900-904.

26. Niu ZY, Liu FZ, Yan QL, et al (2009): Effects of different levels of vitamin $E$ on growth performance and immune responses of broilers under heat stress. Poult Sci, 88, 21012107.

27. Önenç S, Açikgöz Z (2005): Antioxidant effects of aromatic plants on animal products. Hayvansal Üretim, 46, 50-55.

28. Pardue SL, Thaxton JP, Brake J (1985): Influence of supplemental ascorbic acid on broiler performance following exposure to high environmental temperature. Poult Sci, 64, 1334-1338.

29. Sahin K, Ozbey O, Onderci M, et al (2002): Chromium supplementation can alleviate negative effects of heat stress on egg production, egg quality and some serum metabolites of laying Japanese quail. J Nutr, 132, 1265-1268.

30. Salami SA, Majoka MA, Saha S, (2015): Efficacy of dietary antioxidants on broiler oxidative stress, performance and meat quality: science and market. Avian Biol Res, 8, 65-78. 
31. Sari M, Bolat D, Çerçi İH, et al (2008): Hayvan Besleme ve Beslenme Hastalıkları. Medipress Matbaacılık Ltd Şti, Malatya.

32. SPSS IBM (2011): Statistics for Windows, Version 20.0. Armonk, NY, IBM Corp. USA.

33. ST-Pierre N, Cobanov B, Schnitkey G (2003): Economic losses from heat stress by us livestock industries. J Dairy Sci, 86, E52-E77.

34. Stilborn HL, Harris GC, Bottje WG, et al (1988): Ascorbic acid and acetylsalicylic acid (aspirin) in the diet of broilers maintained under heat stress conditions. Poult Sci, 67, 1183-1187.

35. Sugiharto S, Yudiarti T, Isroli I, et al (2017): Effect of dietary supplementation with Rhizopus oryzae or Chrysonilia crassa on growth performance, blood profile, intestinal microbial population, and carcass traits in broilers exposed to heat stress. Arch Anim Breed, 60, 347356.

36. Tatli Seven P, Seven I, Yilmaz M, et al (2008): The effects of Turkish propolis on growth and carcass characteristics in broilers under heat stress. Anim Feed Sci Technol, 146, 137-148.

37. Toplu HDO, Nazligül A, Karaarslan S, et al (2014): Effects of heat conditioning and dietary ascorbic acid supplementation on growth performance, carcass and meat quality characteristics in heat-stressed broilers. Ankara Univ Vet Fak Derg, 61, 295-302.

38. TUIK (2018): Kümes hayvancılığı üretimi. Available at http:// tuikapp. tuik. gov.tr/medas/?kn=80\&locale=tr. (Accessed Sep 20, 2019). 